\title{
REVIEW
}

\section{HIV-1: MATERNAL PROGNOSIS}

Patrícia El Beitune, Geraldo Duarte, Silvana Maria Quintana and Ernesto Antônio Figueiró-Filho

\begin{abstract}
EL BEITUNE P et al. - HIV-1: maternal prognosis. Rev. Hosp. Clín. Fac. Med. S. Paulo 59(1):25-31, 2004.
\end{abstract}
Profound modifications in the profile of patients are currently being observed within the epidemic context of AIDS, especially with respect to pauperization and feminization of the disease. The population most frequently affected is in the reproductive age, and among adults aged 18 to 24 years, the ratio is 1 man to 1 woman, a phenomenon occurring uniformly all over the world. One of the main challenges for HIV-1-infected pregnant women and their doctors is the effect of the interaction between HIV infection and pregnancy. The present article is a review of the literature; and its objective is to assess the influence of HIV-1 infection seen from the maternal perspective, with a discussion of immunologic function, maternal prognosis, and the HIV-abortion interface. At present, we cannot conclude that pregnancy has a short-term effect on the evolution of HIV infection, but the concomitance of HIV and pregnancy may adversely affect the prognosis of gestation, especially in view of its frequent association with increased abortion and puerperal morbidity rates.

DESCRIPTORS: HIV-1. Pregnancy. Abortion. Immunology. Prognosis.

Today women represent the populational segment with the greatest increase in HIV infection. Most of the infected women are in their reproductive age, a fact resulting in 2,100 new infections detected daily in children, almost all of them due to maternal-fetal transmission of HIV ${ }^{1}$. However, advances have been made in the understanding of the pathogenesis of vertical transmission, in parallel with significant progress against maternalfetal transmission of HIV, which has resulted in a new opportunity to renew and fulfill the wish to be a mother for a large segment of the female population. One of the major doubts to be resolved among doctors and patients is the effect of HIV infection on pregnancy and, conversely, the effect of this association on maternal health ${ }^{2}$. The present article is a review of the literature dealing with the influence of HIV-1 infection from the maternal per- spective, with a discussion of immunologic function, the maternal and gestational prognosis, and the HIV-abortion interface.

\section{INFLUENCE OF PREGNANCY ON HIV-INFECTED WOMEN}

The influence of pregnancy on immunologic function remains poorly understood. During the past 10 years, there has been concern that pregnancy itself, either because of associated hormonal changes or because of a pregnancy-related suppression of cellular immunity, leads to an acceleration in the progressive decline of immune

From the Department of Gynecology and Obstetrics, Faculty of Medicine of Ribeirão Preto, University of São Paulo (FMRP-USP) - Ribeirão Preto/SP, Brazil. Received for publication on March 06, 2003. function associated with human immunodeficiency virus (HIV) infection ${ }^{3}$. Reports of small observational series that document clinical deterioration during or within short periods after pregnancy have raised concern about a potentiating effect of pregnancy on HIV infeccion progression ${ }^{4-6}$. From 1985 to 1988, counseling on HIV and pregnancy was influenced by these several negative reports which reflected in the recommendation of abortion in countries like Sweden. ${ }^{7}$

Some studies have reported no effect of pregnancy on the rate of progression of AIDS $^{8-15}$, while others have suggested that an effect could exist ${ }^{5,6,16-18}$.

Currently most HIV-infected women in the world who become pregnant are asymptomatic. Previous investigations of the effects of pregnancy on HIV infection have attempted to characterize the effect of pregnancy on lymphocyte subsets, with inconsistent 
results $^{3,19}$. The correlation between lymphocyte parameters during the antepartum period and the puerperium reflects a stability of these parameters among HIV-infected women during pregnancy, and there is no evidence of a major effect of pregnancy upon the 1 year postpartum outcome of HIV-infected women as measured by changes in lymphocyte subsets (total T-lymphocytes or in CD4+ lymphocytes) ${ }^{3,20-}$ 22 . Other investigations have suggested the occurrence of an initial decrease and then increase or "normalization" in lymphocyte subsets during pregnancy or the postpartum pe$\operatorname{riod}^{19,23-29}$. Degenne et al. ${ }^{29}$ have suggested that a decrease in CD4+ cells occurs as early as the fourth week of gestation. The response to pregnancy of CD8+ lymphocytes is either a slight decrease or stability throughout gestation $^{24,26,27}$. Biggar et al. ${ }^{19}$ observed a more rapid loss of CD4 cells in HIVinfected compared to non-infected women, with a decrease in absolute CD4 cell count during pregnancy through 8 weeks before delivery and a less marked predelivery and postpartum increase. Miotti et al. ${ }^{22}$ observed no differences comparing lymphocyte subsets in HIV-infected and uninfected pregnant women. These authors observed an increase in CD4 and CD8 cells late in pregnancy and immediately postpartum, which then decreased to normal by 6 weeks postpartum. Tuomala et al. ${ }^{3}$ observed a discrete increase in TCD4 cell count during the antepartum period, possibly reflecting a tendency to an improvement of lymphocytic parameters ${ }^{19,22}$. This elevation, however, does not result in an objective normalization of immunologic parameters or in the reduction of complications related to HIV infection, thus representing a fact of probably no clinical relevance ${ }^{3}$.

Burns et al. ${ }^{30}$ demonstrated in a prospective cohort of HIV-1 seropositive pregnant women $(27.5 \%$ of whom received antiretroviral therapy) that in most women, viral load remained stable during pregnancy, but it gradually increased post partum. A significant rise in HIV-1 RNA levels was observed during the second year postpartum (mean increase $0.09 \mathrm{log}$ per year; $p=$ 0.005). Change in HIV-1 RNA was independent of the individual's mean HIV-1 RNA level, mean CD4 cell level, or change in CD4 level ${ }^{31}$. There was a steady decline in CD4 cell levels during the study period. This decline inversely correlated with the individual's mean HIV-1 RNA level. The absence of any significant overall change in HIV-1 viral load during pregnancy could be due to one or more factors. A deleterious effect of the decline of certain immune responses during pregnancy, reported for both HIV-1 seronegative and HIV-1 seropositive women ${ }^{32-34}$ may be offset by other immunologic changes. Pregnancy has been associated with alterations in certain cytokines (in particular, increase in interleukin-10 which has been reported to downregulate HIV-1 replication), endogenous immunomodulators that appear to be very important in modifying HIV-1 replication $^{35-38}$.

Parturition is associated with increased levels of specific cytokines, including interleukin-6 which is capable of upregulating HIV-1 replication, but this alteration appears to be more transient $^{39-40}$.

Investigations suggest that the level of viral load in the peripheral blood is established after seroconversion and remains stable until it begins to rise late in HIV-1 infection $^{41,42}$. This plateau level or "set point", which varies widely, appears to represent the equilibrium reached between the infecting strain of the virus and the capacity of the individual's immune system to contain $\mathrm{it}^{42,43}$. The apparent stability of HIV-1 RNA levels during gestation suggests that preg- nancy has little immediate effect on viral load in most women ${ }^{44}$.

Alliegro et al. ${ }^{45}$ evaluated the incidence and outcome of pregnancy in HIV-infected women with estimated dates of seroconversion and compared the risk of disease progression between women who were pregnant during infection and those who were not. From October 1981 through December 1994, these authors did not observe any effect of the pregnancy up to 1 year after delivery or abortion on accelerated development of AIDS, HIVrelated diseases, or severe immunosuppression during pregnancy. Again, no significant differences were observed between women who were pregnant only once when compared with those with multiple pregnancies.

From survival analysis, it is estimated that 5 years after delivery $14 \%$ of mothers will have died, $24 \%$ will have developed CDC Stage IV disease, and more than $60 \%$ will still be without serious HIV-related manifestations. Women with lower CD4 counts during pregnancy subsequently progressed to CDC Stage IV at a faster rate than women with higher CD4 counts. Thorne et al. ${ }^{46}$ estimated that $66 \%$ of the women with a CD4 count of less than 200 cells $/ \mathrm{mm}^{3}$ will progress to stage 4 within a period of 2 years after delivery, in contrast to only $21 \%$ of women with a CD4 count of more than 499 cells $/ \mathrm{mm}^{3}$.

In a prospective study of the effect of pregnancy on the progression of human immunodeficiency virus infection, there was no difference in progression of disease between child-bearing and non-pregnant HIV-infected women at a 5-year follow-up ${ }^{10}$.

The CCR5 chemokine receptor acts as a coreceptor with CD4 to permit infection by primary macrophagetropic HIV-1 strains. The CCR5Delta32 mutation, which is associated with resistance to infection in homozygous individuals and delayed 
disease progression in heterozygous individuals, is rare in places where the HIV-1 epidemic is growing rapidly. Several polymorphisms in the promoter region of CCR5 have been identified. In this context, John et al. ${ }^{47}$ evaluated the effect of CCR5 promoter mutations on systemic and mucosal HIV-1 replication, disease progression, and perinatal transmission in a cohort of 276 HIV-1-seropositive women in Nairobi, Kenya. These authors demonstrated that women with the $59356 \mathrm{C} / \mathrm{T}$ genotype had a 3.1fold increased risk of death during the 2-year follow-up period and a significant increase in vaginal shedding of HIV-1-infected cells, compared with women with the $59356 \mathrm{C} / \mathrm{C}$ genotype.

\section{INFLUENCE OF HIV-1 ON PREGNANCY}

Whether HIV-1 infection itself may adversely affect pregnancy remains controversial. From 1985 to 1989 , Minkoff et al. ${ }^{48}$ studied the gestational and neonatal prognosis of 92 seropositive and 126 seronegative women who gave birth during the study period and did not observe any demonstrable effect of HIV infection on the gestational prognosis. These data agree with those reported by Selwyn et al. ${ }^{8}$, who studied American female drug users. Similar results were also reported by Johnstone et al. ${ }^{11}$ in a study on female drug users in Edinburgh.

A higher incidence of postpartum genital infection in HIV-seropositive women than in seronegative women has been reported. ${ }^{49-51}$ The power of the study by Minkoff et al. ${ }^{48}$ to detect adverse effects of HIV infection on infrequent complications of pregnancy, such as endometritis or toxemia, is limited $^{48}$. Sexually transmissible diseases and medical complications were diagnosed almost twice as often among seropositive women ${ }^{52}$. After controlling for factors such as sexually transmissible diseases, Leroy et al. ${ }^{49}$ observed a significant increase in adverse obstetrical events, such as maternal postpartum haemorrhage and postoperative endometritis, as also confirmed by other authors ${ }^{50}$.

Some studies have shown an association between HIV-1 infection and miscarriage $\mathrm{e}^{8,11,51,53-63}$, while other authors do not confirm this assertive ${ }^{64-69}$.

In a systematic review of the literature and meta-analysis, Brocklehurst \& French ${ }^{63}$ observed an association between the risk of spontaneous abortion and women infected with HIV-1 that varied from 1.8 to 6 times greater.

Considerable evidence shows that raised anticardiolipin antibody levels are associated not only with thromboembolism but also with preterm delivery, intrauterin growth restriction (IUGR), and fetal loss at all stages of pregnancy ${ }^{70}$. Studies have also demonstrated that raised anticardiolipin antibody levels are uncommon in the general obstetric populations (2\%) and that there is a significantly increased risk of pregnancy wastage when they do occur ${ }^{71,72}$.

Johnstone et al. ${ }^{70}$ in a study of largely asymptomatic, pregnant HIV-seropositive women showed that approximately $25 \%$ had abnormally raised levels of anticardiolipin antibodies, compared with none of the HIV-negative IV drug users or controls. As others have found ${ }^{73-75}$, there seemed to be no association between anticardiolipin antibodies and length of time since seroconversion or overt illness, and the abnormality appeared to be a direct response to $\mathrm{HIV}^{70}$.

Viscarello et al. ${ }^{76}$ observed that $53 \%$ of HIV-1 pregnant women were positive for anticardiolipin antibody. In addition, these authors did not observe association among this positivity and adverse maternal or neonatal outcome, maternal human immunodeficiency virus status, or perinatal trans- mission of virus-seropositive human immunodeficiency.

It is possible that this higher positivity for anticardiolipin antibody is not real. It has been observed that HIV-infected patients often exhibit hypergammaglobulinemia, a potential cause of false-positive results through nonspecific binding of $\mathrm{IgG}^{74}$. Another source of false-positive anticardiolipin levels is heat treatment of serum ${ }^{77}$.

Adverse pregnancy outcome has frequently been reported in HIV infection $^{63}$. However, the hypothesis that part of this effect may result from anticardiolipin antibodies has not been proven. The hypothesis regarding placental size is interesting, since antiphospholipid antibodies may cause placental thrombosis and infarction by blocking the release of arachidonic acid from endothelial cells and hence inhibiting production of prostacyclin ${ }^{70}$.

It seems that there are 2 separate populations of phospholipid antibodies evoked by infectious and autoimmune diseases. Anticardiolipin antibodies evoked by infectious diseases have a narrow specificity for anionic phospholipids complexed to a plasma protein cofactor, and only this group is linked to a thrombotic tendency ${ }^{78-80}$.

Falcón et al. ${ }^{81}$ have suggested that anticardiolipin antibodies may not bind the cardiolipin antigen directly, but may instead bind a plasma protein $\left(b_{2}\right.$-glycoprotein I) that has high affinity for anionic phospholipids. These authors hypothesized that women with antiphospholipid antibodies and a history of pregnancy loss would have a higher prevalence of antibodies against phospholipid-binding proteins than women with antiphospholipid antibodies and normal pregnancies. These authors observed a significant association between IgM anti- $b_{2}$ glycoprotein I and a history of miscarriages. Recurrent spontaneous abortion has been observed owing to alloimunization $^{82}$. 
There may be a direct effect of HIV1 on the placenta and on embriogenesis. HIV-1 has been identified in fetuses during the first weeks of pregnancy ${ }^{83,84}$. The presence of HIV-1 infected monocyte/macrophages in the endometrial mucosa has also been demonstrated ${ }^{85}$. There may be abnormalities in the fetal thymus, with consequent abnormal cytokine production secondarily resulting in an adverse intrauterine milieu for the adequate maintenance of pregnancy, possibly due to the deleterious effects of this event on the endometrium. As a consequence, there may also be a cumulative effect of the immunosuppression caused by HIV infection, facilitating the ascension of infections from the lower genital tract and the development of viral or bacterial infection of the villi ${ }^{68}$. Shearer et al ${ }^{86}$ propose that HIV infection in pregnant women produces an altered state of certain soluble immune factors such as cytokines, which in concert with other immune factor abnormalities such a loss of immune selection in the fetal thymus predisposes the fetus to advanced HIV infection (possibly due to an imbalance of immune factors capable of contributing to immunological rejection) and possible spontaneous abortion.

\section{CONCLUSION}

Current data suggest that pregnancy bears no effect on accelerating the development of AIDS, HIV-related diseases, or severe immunosuppression during pregnancy for up to 1 year after delivery or abortion. On the other hand, HIV infection may adversely affect pregnancy, especially in terms of the overall risk of spontaneous abortion and maternal postpartum endometritis. It would be a useful practice to conduct long-term follow-up on all HIV-infected pregnancies.

\section{RESUMO}

EL BEITUNE P e col. - HIV-1: prognóstico materno. Rev. Hosp. Clín. Fac. Med. S. Paulo 59(1): 25-31, 2004.

Atualmente, dentro do contexto epidêmico da AIDS observam-se profundas modificações no perfil dos pacientes acometidos, especialmente traduzida pela pauperização e feminilização. A população mais afetada encontra-se em idade reprodutiva e entre adultos de 18 a 24 anos, a relação é de 1 homem para
1 mulher, o que ocorre indiscriminadamente como fenômeno global. Um dos maiores desafios para as gestantes portadoras do HIV-1 e seus médicos assistentes é a repercussão advinda da interação entre a infecção pelo HIV e a gestação. Esse artigo é uma revisão de literatura e tem por objetivos avaliar a influência da infecção pelo HIV-1 sob a perspectiva materna tecendo considerações sobre a função imunológica, o prognóstico materno e a interface HIV e abortamento. Até o presente, não se pode concluir que a gestação tenha, a curto prazo, um efeito norteador da evolução da infecção pelo HIV, porém a concomitância HIV e gestação pode adversamente afetar o prognóstico gestacional, especialmente face à freqüente associação com acréscimo nos índices de aborto e morbidade puerperal.

DESCRITORES: HIV-1. Gestação. Abortamento. Imunologia. Prognóstico.

\section{REFERENCES}

1. Joint United Nations Programme on HIV/AIDS (UNAIDS) and World Health Organization (WHO) - AIDS Epidemic Update. UNAIDS/02.46E, December 2002. Disponível em: http:// www.unaids.org.

2. Centers for disease control and prevention (CDC). Public Health Service Task Force recommendations for the use of antiretroviral drugs in pregnant women infected with HIV-1 for maternal health and for reducing perinatal HIV-1 transmission in the United States. MMWR Recommendations and Reports 2002; 51(RR18):1-38.

3. Tuomala RE, Kalish LA, Zorilla C, et al. Changes in total, CD4+, and CD8+ lymphocytes during pregnancy and 1 year postpartum in human immunodeficiency virus-infected women.Obstet Gynecol 1997;89:967-974.
4. Minkoff H, Nanda D, Mendez H, Fikrig S. Pregnancies resulting in infants with acquired immunodeficiency syndrome or AIDSrelated conditions: Follow-up of mothers, children and subsequently born siblings. Obstet Gynecol 1987;69:89-91.

5. Koonin LM, Ellerbrock TV, Atrash HK, et al. Pregnancy-associated deaths due to AIDS in the United States. JAMA 1989;261:13061309 .

6. Scott GB, Fischl MA, Klimas N, et al. Mothers of infants with the acquired immunodeficiency syndrome: evidence for both symptomatic and asymptomatic carriers.JAMA 1985; 253:363366.

7. Lindgren S, Anzen B, Bohlin AB, Lindman K. HIV and childbearing: clinical outcom and aspects of mother-to-infant transmission. AIDS 1991; 5:1111-1116. 
8. Selwyn PA, Shoenbaum EE, Davenny K, et al. Prospective study of human immunodeficiency virus infection and pregnancy outcomes in intravenous drug users. JAMA 1989; 261:12891294.

9. Deschamps MM, Pape JW, Desvarieux M, et al. A prospective study of HIV-seropositive asymptomatic women of childbearing age in a developing country. J Acquir Immune Defic Syndr 1993;6:446-451.

10. Hocke C, Morlat P, Chene G, et al. Prospective cohort study of the effect of pregnancy on the progression of human immunodeficiency virus infection. Obstet Gynecol $1995 ; 86: 886-891$

11. Johnstone FD, Maccallum LR, Brettle R, et al. Does infection with HIV affect the outcome of pregnancy? $\mathrm{Br}$ Med J $1988 ; 296: 467$.

12. Brettle RP. Pregnancy and its effect on HIV/AIDS. In: JOHNSTONE FD - HIV Infection In Obstetrics And Gynaecology. Baillières Clin Obstet Gynaecol 1992; 6:125136.

13. Alger LS, Farley JJ, Robinson BA, et al. Interactions of human immunodeficiency virus infection and pregnancy. Obstet Gynecol 1993; 82:787-796.

14. Mandelbrot L, Henriou R. Does pregnancy accelerate disease progression in HIV-infected women? In: JOHNSON MA, JOHNSTONE FD. - HIV Infection In Women. Edinburgh: Churchill Livingstone 1992. p. 157-171.

15. Lindgren S, Ottenblad C, Bengtsson AB, Bohlin AB. Pregnancy in HIV-infected women. Counseling and care - 12 years' experiences and results. Acta Obstet Gynecol Scand 1998;787:532-541.

16. Minkoff H, De Regt RH, Landesman S, et al. Pneumocystis carinii pneumonia associated with acquired immunodeficiency syndrome in-pregnancy: a report of 3 maternal deaths. Obstet Gynecol 1986; 67:284-287.

17. Gloeb DJ, Shenghan L, Efantis JN, O'Sullivan MJ. Survival and disease progression in human immunodeficiency virus-infected women after an index delivery. Am J Obstet Gynecol 1992; 167:152-157.

18. Vermund SH, Galbraith MA, Ebner SC, et al. Human immunodeficiency virus acquired immunodeficiency syndrome in pregnant women. Ann Epidemiol 1992;2:773803.

19. Biggar RJ, Pahwa S, Minkoff H, et al. Immunosuppression in pregnant women infected with human immunodeficiency virus. Am J Obstet Gynecol1989;161:1239-1244.

20. Coulam CB, Silverfield JC, Kazmar RE, Fathman CG. Tlymphocyte subsets during pregnancy and the menstrual cycle. Am J Reprod Immunol 1983;4:88-90.

21. Glassman AB, Bennett CE, Christopher JB, Self S. Immunity during pregnancy: Lymphocyte subpopulations and mitogen responsiveness. Ann Clin Lab Sci1985; 15:357-362.

22. Miotti PG, Liomba G, Dallabetta GA, et al. T-lymphocyte subsets during and after pregnancy: Analysis in human immunodeficiency virus type1-infected and uninfected Malawian mothers. J Infect Dis 1992;165:146-149.
23. Siridama V, Pacini F, Yang SL, et al. Decreased levels of helper T cells: A possible cause of immunodeficiency in pregnancy. N Engl J Med 1982;307:352-356.

24. Tallon DF, Corcoran KJ, O'Dwyer GM, Greally JF. Circulating lymphocyte subopulations in pregnancy: A longitudinal study. J Immunol 1984; 132:1784-1787.

25. Iwatani Y, Amino N, Tachi J, et al. Changes of lymphocyte sybsets in normal pregnant and postpartum women: Postpartum increases in NK/K (Leu7) cells. Am J Reprod Immunol Microbiol 1988;18:52-55.

26. Bolis PF, Franchi M, Guaschino S, et al. T-lymphocyte subpopulation in pregnancy. Biol Res Perinatol 1983; 4:107109.

27. Barnett MA, Learmonth RP, Pihl E, Wood EC. T- helper lymphocyte depression in early human pregnancy. J Reprod Immunol 1983;5:55-57.

28. Malinowshi A, Szpakowski M, Tchorzewski H et al. T-lymphocyte subpopulations and lymphocyte proliferative activity in normal and pre-eclamptic pregnancies. Eur J Obstet Gynecol Reprod Biol 1994; 53:27-31.

29. Degenne D, Canepa S, Leconte C, et al. Serial study of Tlymphocyte subsets in women during very early pregnancy. Clin Immunol Immunopathol 1988;48:197-201.

30. Burns DN, Landesman S, Minkoff H, et al. The influence of pregnancy on human immunodeficiency virus type 1 infection: Antepartum and postpartum changes in human immunodeficiency virus type 1 viral load. Am J Obstet Gynecol,1998;178:355-359.

31. Burns DN, Nourjah P, Minkoff H, et al. Changes in CD4 and CD8 cells levels during pregnancy and post partum in women seropositive and seronegative for human immunodeficiency virus-1. Am J Obstet Gynecol 1996; 174:1461-468.

32. Weinberg ED. Pregnancy-associated depression of cell-mediated immunity. Rev Infect Dis 1984;6:814-831.

33. Pope RM. Immunoregulatory mechanisms present in the maternal circulation during pregnancy. Baillieres Clin Rheum 1990;4:33-52.

34. Rich KC, Siegel JN, Jennings C, et al. CD4 lymphocytes in perinatal human immunodeficiency virus infection: evidence for pregnancy-induced immune depression in uninfected and HIVinfected women. J Infect Dis 1995;172:1221-1227.

35. Fauci AS. Host factors and the pathogenesis of HIV-induced disease. Nature 1996; 384:529-534.

36. Greig PC, Herbert WN, Robinette BL, et al. Amniotic fluid interleukin-10 concentrations increase through pregnancy and are elevated in patients with preterm labor associated with intrauterine infection. Am J Obstet Gynecol 1995;173:12231227.

37. Montaner LJ, Griffin P, Gordon S. Interleukin-10 inhibits initial reverse transcription of human immunodeficiency virus type 1 and mediates a virustatic latent state in primary blood-derived human macrophages in vitro. J Gen Virol 1994; 75:33943400 . 
El Beitune $\mathrm{P}$ et al.

38. Kollmann TR, Pettoello-Mantovani M, Katopodis NF, et al. Inhibition of acute in vivo human immunodeficiency virus infection by human interleukin 10 treatment of SCID mice implanted with human fetal thymus and liver. Proc Natl Acad Sci USA 1996; 93:3126-3131.

39. Stallmarch T, Hebisch G, Joller H, et al. Expression patterns of cytokines in the different compartments of the feto-maternal unit under various conditions. Reprod Fertil Dev 1995;7:15731580 .

40. Doley A, Serra C, Arch MV, et al. Mutual interactions between HIV-1 and cytokines in adherent cells during acute infection. Arch Virol 1994;134:157-168.

41. Lee-TH, Sheppard HW, Reis M, et al. Circulating HIV-1 infected cell burden from seroconversion to AIDS: importance of postconversion viral load on disease course. J Acquir Immune Defic Syndr 1994;7:371-378.

42. Mellors JW, Kingsley LA, Rinaldo CR, et al. Quantitation of HIV1 RNA in plasma predicts outcome after seroconversion. Ann Intern Med 1995;122:573-579.

43. O'Brien TR, Blattner WA, Waters D. Serum HIV-1 RNA levels and time to development of AIDS in the Multicenter Hemophilia Cohort Study. JAMA 1996; 276:105-110.

44. Fang G, Burger H, Grimson R, et al. Maternal plasma human immunodeficiency virus type 1 RNA level: a determinant and projected threshold for mother-to-child transmission. Proc Natl Acad Sci USA 1995; 92:12100-12104.

45. Alliegro MB, Dorrucci M, Phillips NA, et al. Incidence and consequences of pregnancy in women with known duration of HIV infection. Arch Intern Med. 1997; 157:2585-2590.

46. Thorne C, Newell ML, Dunn D, Peckham C. The European Collaborative Study: clinical and immunological characteristics of HIV 1-infected pregnant women. BJOG 1995; 102:869875.

47. John GC, Bird T, Overbaugh J, et al. CCR5 promoter polymorphism in a Kenyan perinatal human immunodeficiency virus type 1 cohort: association with increased 2-year maternal mortality. J Infect Dis 2001; 184: 89-92.

48. Minkoff HL, Cassandra H, Mendez H, et al. Pregnancy outcomes among mothers infected with human immunodeficiency virus and uninfected control subjects. Am J Obstet Gynecol 1990;163:1598-1604.

49. Leroy V, Ladner J, Nyiraziraje M, et al. Effect of HIV-1 infection on pregnancy outcome in women in Kigali, Rwanda, 19921994. AIDS 1998, 12:643-650.

50. Urbani G, De Vries MM, Cronje HS, et al. Complications assoiated with cesarean section in HIV-infected patients. Int J Gynaecol Obstet 2001; 74:9-15.

51. Duarte G, Quintana SM, Mussi-Pinhata MM et al. Impact of maternal HIV-infection on obstetrical and early neonatal outcome: a nine-year experience (abstract). XI International Conference on AIDS, Vancouver, British Columbia, Canada, June, 1996: Tu. C. 2572

52. Ryder RW, Nsa W, Hassia SE, et al. Prenatal transmission of the human immunodeficiency virus type 1 to infants of seropositive women in Zaire. N Engl J Med 1989; 320:18371842.
53. Lasley-Bibbs V, Renzullo P, Goldenbaum M, et al. Patterns of pregnancy and reproductive morbidity among HIV-infected women in the United States Army: a retrospective cohort study. VI Internacional Conference on AIDS. San Francisco, June 1990 (abstract TH.C. 655).

54. Stephenson JM, Griffioen A, Study group for the medical research council collaborative study. The effect of HIV diagnosis on reproductive experience. AIDS 1996; 10: 1683-1687.

55. De Vincenzi I, Jadand C, Couturier E, et al. Pregnancy and contraception in a French cohort of HIV-infected women. AIDS 1997; 11:333-338.

56. Braddick MR, Kreiss JK, Embree JE, et al. Impact of maternal HIV infection on obstetrical and early neonatal outcome. AIDS 1990; 4:1001-1005.

57. Miotti PG, Dallabetta G, Ndovi E, et al. HIV-1 and pregnant women: associated factors, prevalence, estimate of incidence and role in fetal wastage in central Africa. AIDS 1990; 4: 733736.

58. Miotti PG, Dallabetta G, Chiphangwi JD, et al. A retrospective study of childhood mortality and spontaneous abortion in HIV-1 infected women in urban Malawi. Int J Epid 1992; 21: 792-799.

59. Lepage P, Dabis F, Hitimana DG, et al. Perinatal transmission of HIV-1: Lack of impact of maternal HIV infection on characteristics of livebirths and on neonatal mortality in Kigali, Rwanda. AIDS 1991, 5:295-300.

60. De Cock KM, Zadi F, Adjorlolo G, et al. Retrospective study of maternal HIV-1 and HIV-2 infections and child survival in Abidjan, Cote d'Ivoire. BMJ 1994; 308: 441-443.

61. Desgrées Du Loû A, Msellati P, Ramon R, et al. HIV-1 infection and reproductive history: a restrospective study among pregnant women, Abidjan, Côte d'Ivoire, 1995-1996. Int J STD \& AIDS 1998, 9: 452-456.

62. Ryder RW, Batter VL, Nsuami M, et al. Fertility rates in 238 HIV1 seropositive women in Zaire followed for 3 years postpartum. AIDS 1991; 5:1521-1527.

63. Brocklehurst P, French R The association between maternal HIV infection and perinatal outcome: a systematic review of the literature and meta-analysis. BJOG, 1998; 105: 836-848.

64. Temmerman M, Chomba EN, Ndinya-Achola J, et al. Maternal human immunodeficiency virus-1 infection and pregnancy outcome. Obstet Gynecol 1994; 83:495-501.

65. Sunderland A, Minkoff HL, Handte J, et al. The impact of human immunodeficiency virus serostatus on reproductive decisions of women. Obstet Gynecol 1992; 79: 1027-1031.

66. Lindsay MK, Grant J, Peterson HB, et al. The impact of knowledge of human immunodeficiency virus serostatus on contraceptive choice and repeat pregnancy. Obstet Gynecol 1995; 85:675679 .

67. Chirgwin K, Feldman JG, Driscoll B, et al. Pregnancy outcome in HIV-infected women. IX International Conference on AIDS Berlin, June 1993 (abstract PO B23 1946).

68. D'ubaldo C, Pezzotti P, Rezza G, et al. Association between HIV1 infection and miscarriage: a retrospective study. AIDS 1998; 12: 1087-1093. 
69. Bakas C, Zarou DM, Caprariis PJ. First-trimester spontaneous abortions and the incidence of human immunodeficiency virus seropositivity. J Reprod Med 1996; 41: 15-18.

70. Johnstone FD, Kilpatrick DC, Burns SM. Anticardiolipin antibodies and pregancy outcome in women with human immunodeficiency virus infection. Obstet Gynecol 1992; 80:92-96.

71. Lockwood CJ, Romero R, Feinberg RG, et al. The prevalence and biologic significance of lupus anticoagulant and anticardiolipin antibodies in a general obstetric population. Am J Obstet Gynecol 1989; 161: 369-373.

72. Perez MC, Wilson WA, Brown ML, Scopetlitis E Anticardiolipin antibodies in unselected pregnant women: Relationship to fetal outcome. J Perinatol 1991; 11: 33-36.

73. Boue F, Dreyfus M, Bridey F, et al. Lupus anticoagulant and HIV infection: A prospective study. AIDS 1990; 4:467-468.

74. Maclean C, Flegg PJ, Kilpatrick DC. Anticardiolipin antibodies and HIV infectin. Clin Exp Immunol 1990; 81: 263-266.

75. Bernard C, Exquis B, Reber G, De Moerloose P. Determination of anti-cardiolipin and other antibodies in HIV-1 infection patients. J Acquir Immune Defic Syndr 1990; 3:536-539.

76. Viscarello RR, Williams CJ, Degennaro NJ, Hobbins JC. Prevalence and prognostic significance of anticardiolipin antibodies in pregnancies complicated by human immunodeficiency virus1 infection. Am J Obstet Gynecol 1992; 167(4 Pt 1): 10801085 .

77. Hasselaar P, Triplet DA, Larue A, et al. Heat treatment of serum and plasma induces false positive results in the antiphospholipid antibody ELISA. J Rheumatol 1990; 17: 186-191.
78. Harris EN, Gharavi AE, Wasley GD, Hughes GRV. Use of an enzyme-linked immunosorbent assay and of inhibition studies to distinguish between antibodies to cardiolipin from patients with syphilis or autoimmune disorders. J Infect Dis 1988; 157: 23-31.

79. Loizou S, Mackworth-Young CG, Cofiner C, et al. Heterogeneity of binding reactivity to different phospholipids of antibodies from patients with systemic lupus erythematosus (SLE) and with syphilis. Clin Exp Immunol 1990; 80: 171-176.

80. McNeil HP, Hunt JE, Krilis AS. New aspects of anticardiolipin antibodies. Clin Exp Rheumatol 1990; 8: 525-527.

81. Falcón CR, Martinuzzo ME, Forastiero RR, et al. Pregnancy loss and autoantibodies against phospholipid-binding proteins. Obstet Gynecol 1997; 89:975-980.

82. Wang Y, Underwood J, Vaughan R, et al. Allo-immunization elicits CCR5 antibodies, SDF-1 chemokines and CD8-supressor factors that inhibit transmission of R5 and X4 HIV-1 in women. Clin Exp Immunol 2002; 129(3): 493-501.

83. Maury W, Potts BJ, Rabson AB. HIV-1 infection of first trimester and term human placental tissue: a possible mode of maternalfetal transmission. J Infect Dis 1989; 160: S83-88.

84. Sprecher S, Soumenkoff G, Puissant F, Degueldre M. Vertical transmission of HIV-1 in 15 week fetus. Lancet 1986; ii:288289.

85. Peuchmaur M, Emilie D, Varzeux R, et al. HIV-associated endometritis. AIDS 1989; 3:239-241.

86. Shearer WT, Reuben J, Popek EJ, et al. Role of placental cytokines and inflammation in vertical transmission of HIV infection. Acta Paediatr Suppl 1997; 421: 33-38. 